Silva Forné, Diego, “Punitivismo, legislación de urgencia y pandemia en Uruguay:

Los atajos del autoritarismo contra el estado de derecho", Nuevo Foro Penal 96, (2021).

\title{
Punitivismo, legislación de urgencia y pandemia en Uruguay: \\ Los atajos del autoritarismo contra el Estado de derecho
}

Punitivism, urgency legislation and pandemic in uruguay:
The shortcuts of authoritarianism against the rule of law

Fecha de recepción: 22/12/2020. Fecha de aceptación: 26/04/2021

DOI: $10.17230 /$ nfp17.96.2

DiEgo Silva Forné*

\section{Resumen}

A través de un procedimiento legislativo anómalo y en medio de una emergencia sanitaria, se aprobó en Uruguay una extensa ley conteniendo numerosas disposiciones de corte represivo, con impacto sobre todo el sistema penal. Se ponen en juego diversos derechos fundamentales y garantías, se incrementan las potestades del aparato policial y se abre la puerta a un crecimiento de la población penitenciaria sin precedentes, incurriendo a su vez en diversas inconstitucionalidades de fondo y de forma, socavando el Estado de Derecho.

* $\quad$ Doctor en Ciencias Sociales y Jurídicas por la Universidad de Cádiz. Profesor Agregado de Derecho Penal de la Facultad de Derecho de la Universidad de la República, Uruguay. Integrante del Sistema Nacional de Investigadores del Uruguay (SNI-ANII). Investigador Responsable del Grupo de Estudios en Política Criminal de Uruguay (Comisión Sectorial de Investigación Científica - Universidad de la República). Contacto: dsilvaf2@gmail.com. 
El análisis devela un caso de desnaturalización de institutos constitucionales -práctica que, a través de distintas formas, se ha extendido en nuestro Continente- utilizado aquí con fines punitivistas.

\section{Abstract}

Through an anomalous legislative procedure and in the midst of a health emergency, an extensive law was approved in Uruguay containing numerous provisions of a repressive nature, with an impact on the entire penal system. Various fundamental rights and guarantees are put into play, the powers of the police apparatus are increased and the door is opened to an unprecedented increase in the prison population, in turn incurring various fundamental and formal unconstitutionalities, undermining the rule of law. The analysis reveals a case of denaturalization of constitutional institutes -a practice that has spread throughout our Continent through different forms- used here for punitive purposes.

\section{Palabras clave}

Punitivismo, legislación de urgencia, Estado de Derecho, Estado policial, libertades fundamentales, COVID-19.

\section{Keywords}

Punitivism, emergency legislation, rule of law, police state, fundamental freedoms, COVID-19

\section{Sumario}

1. Introducción. Inconstitucionalidad y pandemia. 2. Populismo punitivo. La ley penal como herramienta de prima ratio. 3. La técnica legislativa y la dosimetría de las penas. 4. Hacia un inconstitucional Estado de policía. 5. La desnaturalización de la legítima defensa. 6. El retorno de la fracasada "guerra a las drogas". 7. Criminalización de la disidencia, la protesta y la pobreza. 8. Violación del principio de separación de poderes. 9. Hacia el colapso del sistema penitenciario. 10. Balance. Bibliografía.

\section{Introducción. Inconstitucionalidad y pandemia}

El 9 de julio de 2020 fue promulgada en Uruguay la Ley No 19.889, de Urgente Consideración. Culminaba así un proceso legislativo anómalo, a través del cual el nuevo gobierno asumido el $1^{0}$ de marzo del mismo año -integrado por una coalición de todas las derechas- presentó al Parlamento un proyecto de ley a través del procedimiento de urgente consideración previsto por el numeral $7^{0}$ del art. 168 de la 
Constitución de la República Oriental del Uruguay; se trata de un trámite excepcional, donde el Poder Legislativo cuenta con plazos muy breves para el tratamiento del proyecto, vencidos los cuales en cada Cámara, éste se reputa como aprobado.

Dicho procedimiento se ha utilizado contadas veces desde su introducción en la Constitución uruguaya vigente, de 1967. Cuando fue utilizado para aprobar legislativamente varios temas conjuntamente, fue cuestionada su constitucionalidad, en tanto no emergía la urgencia necesaria para emplear este procedimiento excepcional para diversos temas; el más extenso de estos textos hasta entonces, apenas superaba los ochenta artículos.

El proyecto de ley remitido en abril de 2020 por el Poder Ejecutivo uruguayo para su consideración parlamentaria a través del procedimiento de urgente consideración, contenía más de quinientos artículos. En ellos se plasmaba buena parte del programa del gobierno electo, con importante énfasis en la "seguridad pública" (así se denominaba su primera sección, con diez capítulos y ciento veinte artículos), incluyendo la modificación de numerosas disposiciones penales y procesales en sentido represivo, así como otorgando nuevas potestades a la Policía, varias de ellas flagrantemente inconstitucionales. El autoritarismo ha asumido nuevas vías en el siglo XXI para obtener sus fines, desnaturalizando los procedimientos constitucionales; se trata de un evidente abuso de derecho, materializado a través del fraude a la Constitución.

En efecto, la diversa variedad de temas contenidos en el proyecto y su desmesurada extensión, hizo materialmente imposible que pudieran analizarse seria y serenamente, teniendo en cuenta los breves plazos parlamentarios de este procedimiento; ello determina que el abuso o exceso de poder se verifique objetivamente, en tanto el resultado producido por el actuar del órgano (el Poder Ejecutivo) no coincide con el fin para el cual se le confirió el poder ejercido' ${ }^{1}$, resultando una inconstitucionalidad por razón de forma al tramitar por un procedimiento excepcional lo que debería haber sido objeto de múltiples proyectos de ley, así como por razón de contenido, en tanto resultaba imposible predicar la urgencia respecto de cada uno de los numerosos temas abarcados por el proyecto.

Se trató también de una violación del principio de separación de poderes, en tanto el Poder Ejecutivo impuso al Poder Legislativo un procedimiento anómalo, donde los legisladores no contaron con la posibilidad de estudiar detenidamente cada uno de los diversos temas contenidos en el proyecto, muchos de ellos involucrando derechos fundamentales. En definitiva, el Poder Ejecutivo prescinde implícitamente 
del Legislativo para gobernar, enmascarando con una pátina de legitimidad aquello que lesiona flagrantemente el Estado de Derecho.

A su vez, la tramitación legislativa se dio durante una situación mundial excepcional: la pandemia por el COVID-19. Uruguay se encontraba durante un Estado de Emergencia Sanitaria, con lógicas limitaciones para el ejercicio del derecho de reunión, menoscabando la libre comunicación del pensamiento e impidiendo la realización de manifestaciones públicas que pudieran expresar disidencias, reclamos o protestas. Ello imposibilitó la plena participación de la sociedad civil en el debate de decenas de temas de singular trascendencia, por lo que resultaba ilógico tramitar este extensísimo proyecto de ley en medio de medidas sanitarias fundadas pero que implicaban también el recorte de libertades fundamentales, lo que evidenciaba la manifiesta inconveniencia de utilizar el citado procedimiento legislativo extraordinario durante una pandemia sin precedentes en los últimos cien años.

Resulta incontrovertible que la Constitución ha de cumplirse de buena fe. Como se señalara entonces, en torno a esta situación: "La legitimidad de la solución legislativa se asienta en el carácter representativo del ejercicio de la soberanía, que radica en el pueblo. El régimen de funcionamiento bicameral del parlamento, la cantidad de miembros y su forma de elección, procuran obtener un reflejo lo más fiel posible y una confrontación plural y ecuánime de posiciones, lo que oficia de garantía en el proceso de formación de la ley penal"2.

Ello no fue cumplido en el proceso de sanción de esta ley. Si bien no se produjo la aprobación ficta en las Cámaras y los legisladores recibieron informes y comparecencias de diversas instituciones y colectivos, el caudal de información fue tan grande teniendo en cuenta la enorme profusión de temas contenidos en más de quinientos artículos proyectados, que resultaba evidente que no había espacio para el análisis de los diversos aportes, la reflexión, el intercambio abierto y la ponderación de las propuestas frente a sus críticas y alternativas así como respecto de las soluciones preexistentes, muchas de aquéllas de alta complejidad e impacto, en sesiones maratónicas con plazos exiguos.

Lamentablemente, América Latina cuenta ya con experiencia en esta modalidad de hacer política desnaturalizando las potestades constitucionales con que cuentan las autoridades de turno. Lo novedoso aquí es que el objetivo no viene dado por la persecución política o un golpe de estado encubierto, sino por la sanción

2 Centro de Investigaciones y Estudios Penales del Uruguay “Dra. Adela Reta” (CiepuR) y Grupo de Estudios en Política Criminal (GEPCU), Informe al Senado sobre el proyecto de ley de urgente consideración, comparecencia del 22.05.2020. Recuperado de https://parlamento.gub.uy/documentosyleyes/fichaasunto/145885/ficha _ completa; consulta: 20.07.2020. También en www.ciepur.com.uy. 
de un aluvión de normas penales a través de un procedimiento legislativo abreviado, impidiendo de facto la contrastación del discurso populista punitivo con los datos de la ciencia, la participación de la sociedad civil y la reflexión ponderada de los legisladores.

\section{Populismo punitivo. La ley penal como herramienta de prima ratio}

Los analistas sociales coinciden en que Uruguay es un país que cuenta con un bajo índice de violencia en el contexto regional y sin embargo su población en las encuestas reiteradamente suele manifestarse insegura. En ello no debe resultar un dato ajeno que la pirámide poblacional del Uruguay es la de un país envejecido, con bajas tasas de natalidad y relativamente alta expectativa de vida; paradójicamente a su vez, esta "sensación térmica" de inseguridad florece cuando es promocionado en el extranjero como destino caracterizado por su tranquilidad y seguridad.

De acuerdo con el Informe sobre Desarrollo Humano 2019 del PNUD, Uruguay se encuentra dentro de los tres países de América Latina catalogados como de desarrollo humano muy alto. Conforme el Global Peace Index de 2019, Uruguay es el país más seguro de Latinoamérica, lugar que mantiene en el informe $2020^{3}$. Sin embargo, la Exposición de Motivos del proyecto de ley afirmaba que el país se encontraba en una situación de inseguridad casi apocalíptica ${ }^{4}$, visión que

3 El Índice de Paz Global (GPI) es un indicador que mide el nivel de paz y la ausencia de violencia de un país o región. Es elaborado y publicado desde el año 2007 por el Institute for Economics and Peace junto a varios think tanks y el Centre for Peace and Conflict Studies de la Universidad de Sydney, con datos procesados por la Unidad de Inteligencia del semanario británico The Economist.

4 Exposición de Motivos del proyecto de ley (Ley No 19.889): “... el articulado que comprende la Sección I tiene por objeto principal establecer una serie de normas legales a los efectos de reestablecer, en el menor plazo posible, las condiciones necesarias para asegurar la convivencia pacífica de las personas que habitan nuestro país. En el sentido indicado precedentemente, es imprescindible recuperar una convivencia segura y pacífica; la seguridad es un derecho fundamental de las personas, y garantizar la seguridad de las personas y de las familias es un deber del Estado irrenunciable. Uruguay fue considerado durante mucho tiempo un país seguro $y$, en los últimos años, la inseguridad ha ido agravándose cada vez más a pesar de las estructuras y el accionar para revertir la tendencia. Pese ser un cometido esencial indelegable en virtud de su naturaleza, las cifras demuestran que el Estado se ha vuelto ineficaz como garante de la seguridad de las personas. Para recuperar la calidad de nuestra convivencia es necesario poner al Estado en condiciones de ejercer adecuadamente sus funciones de prevención, disuasión y represión del delito, así como también un conjunto de acciones complementarias que doten al sistema de la eficacia requerida para transformar y erradicar la situación actual. El articulado propuesto forma parte de una visión que trasciende el concepto de seguridad pública para incluir la noción de seguridad ciudadana, que se vuelve esencial cuando se requiere, con urgencia, un marco jurídico e institucional que respalde el accionar policial y las políticas de seguridad 
constituyó argumento central de la campaña electoral de la coalición vencedora en los comicios, celebrados en octubre de 2019, tema destacado también en la agenda de los mass media. Las campañas de ley y orden no son una novedad en nuestro continente, tampoco las pulsiones espasmódicas del Estado Policial; lo singular de este caso radica en la concreción legislativa del populismo punitivista a través del procedimiento extraordinario mencionado y en la particular coyuntura de excepción ${ }^{5}$.

Desde fines del siglo XX y potenciada por la sociedad de la información, nos encontramos con una clase política que cada vez con mayor frecuencia recurre ante cualquier tema a la legislación penal, dejando de lado su reconocido carácter de última ratio. La inmediatez que caracteriza a la vida contemporánea, repercute en la labor legislativa en tanto pareciera que el legislador se encuentra en campaña electoral permanente, atento siempre a las encuestas de opinión y sopesando cada decisión en términos electorales, lo que incide decisivamente en su consideración de la bondad o no de cada solución legislativa, con franco desmedro de la técnica y los datos de la ciencia. Así, la legislación pretende dar respuesta a controversias coyunturales, consolidando la mistificación de la ley como presunta herramienta de sanación universal. La demagogia y el discurso populista anclan en esta perspectiva, resultando de tanta o mayor relevancia política la labor legislativa como la comparecencia mediática.

Sin embargo, resulta evidente que la mera actividad legislativa no modifica de por sí la realidad, sino que son diversos factores los que deben sumarse para dar efectividad a lo dispuesto por una norma. Esta mistificación de la ley debe visibilizarse para permitir, en sentido positivo, una consolidación de la legalidad dentro del marco constitucional en defensa de los derechos de la población, y en sentido negativo, para rechazar su utilización puramente simbólica, cuestionando el furor legiferante que pretende dar la impresión de que con la sanción de una ley se soluciona cualquier problema.

No obstante, la asunción del discurso punitivista, con la facilidad de su difusión por los medios masivos de comunicación y la banalización de la complejidad social que implica respecto de las situaciones problemáticas que reduce, parece permear todo el espectro político en las democracias de Occidente. Por supuesto que el

pública". La legislación uruguaya vigente puede ser consultada en la web oficial www.impo.com.uy.

5 En virtud de la situación sanitaria imperante, las expresiones de la sociedad civil organizada, en un país con un importante activismo y nivel de participación, quedaron sensiblemente restringidas. Inclusive y dada la brevedad de los plazos legislativos de urgencia, las organizaciones sociales que tuvieran aportes que hacer llegar a la Comisión Especial del Senado que trató el proyecto, eran recibidas una tras otra cada quince minutos en sesiones que se extendían durante todo el día, con lo que el intercambio de los legisladores con la ciudadanía fue prácticamente simbólico. 
énfasis viene puesto en los delitos contra la propiedad o cometidos mediante violencia, característicos de los sectores sociales desfavorecidos, ya que en ningún caso el reclamo punitivista alcanza a la delincuencia económica ni empresarial. Las fuerzas políticas conservadoras lo sostienen pues ha sido y es históricamente -junto con la rebaja de los impuestos y la reducción del Estado- su principal argumento electoral: el reclamo por mayor "seguridad", lo que se articula a través de mayor represión policial y restricción de derechos fundamentales. Las fuerzas políticas progresistas lo admiten en tanto no quieren aparecer mediáticamente como "débiles" frente al delito ni suelen contar con una estrategia político-criminal definida en sus programas de gobierno. Con fina ironía ha descrito Simon este discurso simplista y maniqueo en relación con la política norteamericana, lo que en varios aspectos puede extrapolarse a otras realidades: "...para estar a favor de la gente, los legisladores deben estar a favor de las víctimas y de las fuerzas del orden público y, por ende, nunca deben ponerse (o ser susceptibles de que se los acuse de ponerse) del lado de los delincuentes o los prisioneros, como individuos o como clase. Hacerlo equivale a una condena por dos motivos. En primer lugar, en el orden personal revela una permisividad o tolerancia hacia el delito que resulta descalificadora. En segundo lugar, significa tomar partido en contra de las víctimas y los agentes del orden en un juego que no aporta ningún punto a favor, donde cualquier beneficio para los prisioneros 0 delincuentes es vivido como una pérdida para las fuerzas del orden y las víctimas".

Y a su vez, pese a su gravedad y extendida dañosidad, se ignora absolutamente la delincuencia económica y empresarial, cuya tipificación en Uruguay es prácticamente inexistente, inclusive tras la debacle financiera provocada por la profunda crisis económica acaecida en el año 2002; ello ratifica que el discurso punitivista continúa históricamente centrado en los delitos que cometen los mismos sectores sociales de la población ${ }^{8}$ y que -como se vio, en forma similar a lo que

6 Simon, Jonathan, Gobernar a través del delito Governing Through Crime: How the War on Crime Transformed American Democracy and Created a Culture of Fear, Oxford University Press, New York, 2007; traducción de Victoria de los Ángeles Boschiroli), Gedisa, Barcelona - México D. F., 2011, p. 141.

7 Véase en Silva Fonné, Diego, La Reforma Penal. El derecho vigente. Modificaciones proyectadas. Alternativas, Fundación de Cultura Universitaria, Montevideo, 2012, pp. 178 y ss. y pp. 246 y ss.; más recientemente y con profusa argumentación, Terradillos Basoco, Juan, “Caracteres y Principios Generales del Derecho Penal Económico y de la Empresa", en Silva Forné, Diego / Uval, Natalia (Coords.), Reforma del Código Penal. Aportes de las organizaciones sociales y de juristas internacionales, Cámara de Representantes - Oficina de Planeamiento y Presupuesto - Unión Europea, Montevideo, 2016, pp. 189 y ss.

8 Wacouant, Loïc, Castigar a los pobres. El gobierno neoliberal de la inseguridad social (Punishing the 
acontece en otras latitudes- aunque con importantes matices, no reconoce límites definidos en el sistema uruguayo de partidos ${ }^{9}$.

No se trata de una problemática exclusiva del Uruguay; diversos analistas contemporáneos asocian estos procesos con la crisis del Estado benefactor y el entronizamiento de la sociedad de consumo propia de la posmodernidad ${ }^{10}$. En tal sentido señalaría Castel que, al menos en los países desarrollados, se vive en las sociedades más seguras que jamás hayan existido, pero sin embargo, aún en estas sociedades rodeadas y atravesadas por todo tipo de protecciones, las preocupaciones por la seguridad permanecen omnipresentes: "La vida es un riesgo porque lo incontrolable está inscripto en su desarrollo. Habría que interrogarse más sobre la inflación actual de la preocupación por la prevención, que es estrictamente correlativa de la inflación de la preocupación por la seguridad (...) la ideología de la prevención generalizada está condenada al fracaso. Pero el deseo desesperado de erradicar el peligro que conlleva, nutre una forma de angustia probablemente específica de la modernidad, y que es inextinguible (. . .) la búsqueda de la seguridad absoluta puede entrar en contradicción con los principios del Estado de Derecho y se desliza fácilmente hacia una pulsión de seguridad que persigue a los sospechosos y se satisface a través de la condena de chivos emisarios. El fantasma de 'nuevas clases peligrosas' que constituirían los jóvenes de los suburbios pobres, ejemplifica este tipo de desviación"11. 0 como diría Bauman: "La generación tecnológicamente mejor equipada de la historia humana es la más acuciada también por sentimientos como la inseguridad y la impotencia (...) contra toda 'evidencia objetiva', también somos nosotros -las personas más mimadas y consentidas de todos los tiempos- los que nos sentimos más amenazados, inseguros y asustados, los más inclinados a ser presa del

Poor. The Neoliberal Government of Poverty, Duke University Press, Durham and London, 2009; traducción de Margarita Polo, Diego P. Roldán y Cecilia Pascual), Gedisa, Barcelona, 2010, pp. 29 y ss.

9 En tal sentido, se ha señalado respecto a la situación en Uruguay: "Este 'populismo penal desde arriba' ha adquirido ritmos y formas distintos, según las exigencias de los hechos y las inclinaciones político-ideológicas de los gobiernos"; en Mosteriro, Mariana/ Samudo, Tamara et al., "Adolescentes, jóvenes y violencia policial en Montevideo. Una aproximación descriptiva", Cuadernos de Ciencias Sociales y Políticas Sociales No 6, SERPAJ - IELSUR - Facultad de Ciencias Sociales/Facultad de Ciencias Económicas y Administración (UdelaR) - Ministerio de Desarrollo Social, Montevideo, 2016, p. 15.

10 Garland, David, La cultura del control. Crimen y orden social en la sociedad contemporánea (The Culture of Control-Crime and Social Order in Contemporary Society, Oxford University Press, 2001; traducción de Máximo Sozzo), Gedisa, Barcelona, 2005, pp. 313 y ss.

11 CAStel, RoBert, La inseguridad social ¿Qué es estar protegido? (L'insécurité sociale. Qu'est-ce qu'être protégé?, Éditions du Seuil et La République des Idées, Paris, 2003; traducción de Viviana Ackerman), Ediciones Manantial, Buenos Aires, 2004, pp. 11-12 y 114-115. 
pánico, y los más apasionados por todo lo relacionado con la protección y la seguridad, de todos los miembros de cualquier sociedad de la que se haya tenido noticia"'12.

Por otra parte, el sentimiento de inseguridad se afianza ante situaciones de "pánico moral", las que constituyen procesos sociales durante los cuales se identifica un hecho como amenazante y a la vez se señala un enemigo interno que lo encarna, constituyendo un peligro para la "gente común"; y en este proceso, como destaca KeSSLER, los medios juegan un rol central al colocar en primer plano ciertos temas. Ello no supone que todo delito genere pánico moral (la delincuencia económica es uno de ellos) ni que una sociedad viva en pánico moral porque el delito haya aumentado ${ }^{13}$. En efecto, investigaciones contemporáneas señalan que no existe una linealidad entre probabilidad "objetiva" de victimización en determinado contexto y la sensación mayor o menor de inseguridad -como percepción individual de riesgo-, en la población de un mismo lugar; así, puede afirmarse que no existe una relación directa entre las alteraciones en las tasas de criminalidad y la percepción subjetiva de inseguridad, siendo ésta el producto de una construcción social compleja dentro de la cual el riesgo real de victimización, sea cual fuere, ocupa un lugar relativamente marginal ${ }^{14}$.

Así como la obsesión securitaria no tiene fin y en definitiva alimenta una ilusión inalcanzable, el punitivismo -correlato de la anterior- tampoco lo tiene, dado que siempre toda medida termina pareciendo insuficiente y habilita el reclamo de mayor represión, con lo que esta lógica inacabable -en tanto parte de premisas erróneas, de imposible cumplimiento- en su progresión culmina poniendo en cuestión el propio Estado de Derecho. La reflexión político criminal contemporánea ha advertido del camino sin salida a que lleva un enfoque centrado en la seguridad ciudadana, el cual, conforme señalara Bustos RAmírez, se tiende a vincular a la delincuencia violenta: ". . .luego la inseguridad en su aspecto objetivo y subjetivo, que es la otra cara del problema como cuestión

12 Bauman, Zygmunt, Miedo líquido. La sociedad contemporánea y sus temores (Liquid Fear, Polity Press, Cambridge, 2006; traducción de Albino Santos Mosquera), Paidós, Barcelona, 2007, pp. 131-132.

13 Kessler, Gabriel, El sentimiento de inseguridad. Sociología del temor al delito, Siglo XXI, Buenos Aires, 2011, pp. 64-66.

14 Por ejemplo, para sociedades muy diferentes, Kury, Helmut/ Ferdinand, Theodore, "Miedo al delito, tamaño de la población, salidas a la calle y actitudes hacia la policía. Resultados alemanes", Revista de Derecho Penal y Criminología, $2^{a}$ época, No 3, U.N.E.D., Madrid, 1999, p. 260 y Ribeiro Giambardino, André, "A construção social do medo do crime e a violencia urbana no Brasil", Revista Brasileira de Ciências Criminais, vol. 115, año 23, IBCCrim/Thomson Reuters/Revista dos Tribunais, São Paulo, 2015, p. 226. 
a resolver, queda también reducida sólo a la violencia callejera"15. De esta manera, en un enfoque reduccionista de la seguridad y de olvido de las causas y factores vinculados a la inseguridad, se focaliza la atención en los delitos de violencia callejera, quedando fuera de ella la delincuencia menos visible, de impacto mediato pero no menos dañosa, especialmente la criminalidad económica, con lo cual se profundiza un enfoque clasista en la respuesta penal ${ }^{16}$. En tal sentido, continúa Bustos Ramírez: "Resulta fácil para el Estado reducir la inseguridad a la violencia, pues ello permite que queden encubiertos todos los procesos económicos, sociales y culturales que configuran la inseguridad y por otra parte se puede circunscribir sin mayor problema el grupo de sujetos que con su comportamiento o presencia originan la inseguridad. Además con ello el tema sólo queda reducido a los más desfavorecidos dentro de la sociedad, pues ciertamente son los excluidos socialmente los que por sus habilidades y por la formación social recibida sólo están en condiciones de llevar a cabo actos de violencia callejera, ya que en caso alguno podrían hacer quebrar un banco, sacar ilegítimamente dineros al exterior, o gerenciar indebidamente una sociedad anónima, etc. De este modo también el delincuente de cuello blanco queda fuera de este Estado de seguridad. La preocupación y el temor de la sociedad, de los medios de comunicación de masas y de los cientistas sociales están referidos exclusivamente a los violentos"17.

Por otra parte, los sectores sociales más desfavorecidos suelen ser quienes en mayor medida experimentan la delincuencia callejera, no obstante sus reclamos no suelen impactar en los medios como los de los sectores acomodados, de los que suelen derivarse medidas securitarias adoptadas por los gobiernos; ello ratifica que no solamente la legislación penal es eminentemente clasista (pese a que el concepto de clase esté "en crisis", no encontramos aún otro mejor), sino también la praxis del aparato penal.

\section{La técnica legislativa y la dosimetría de las penas}

Los análisis contemporáneos sobre Teoría de la Legislación se abocan a delinear pautas de racionalidad y eficacia legislativas. Entre numerosos trabajos al respecto en las últimas décadas, quienes han prestado especial atención a estos análisis

15 Bustos Ramírez, Juan, "Seguridad ciudadana y seguridad jurídica", Nuevo Foro Penal No 70, Universidad EAFIT, Medellín, 2006, p. 163.

16 Terradillos Basoco, Juan, "Las reformas penales españolas de 2003: valoración político-criminal", Nuevo Foro Penal № 67, Universidad EAFIT, Medellín, 2005, p. 144.

17 Bustos Ramírez, "Seguridad ciudadana y seguridad jurídica", cit., p. 164. 
destacan el modelo de ATIENZA, el que distingue cinco planos en la racionalidad de la legislación: i) la racionalidad lingüística o comunicativa, en cuanto a que el emisor de la ley tiene que transmitir con éxito un mensaje normativo al destinatario; ii) la racionalidad jurídico-formal o sistemática, en el sentido de que toda ley tiene que insertarse coherente y consistentemente en un ordenamiento jurídico preexistente a su promulgación; iii) la racionalidad pragmática, que expresa el grado en que las leyes cobran eficacia 'real' o son cumplidas u observadas; iv) la racionalidad teleológica o instrumental, es decir, la idoneidad de la ley para alcanzar los objetivos que persigue; v) la racionalidad ética, en cuanto los fines y contenidos de la ley presuponen valores que deberían ser éticamente justificables, es decir, legítimos; vi) la eficiencia, dimensión transversal que atiende al logro de un equilibrio o ajuste razonable entre los demás niveles ${ }^{18}$.

En el plano del Derecho Penal, entre el profundo y detallado análisis de diversos aspectos de esta problemática, Díez Ripollés reseña la perspectiva de Vogel, quien en la línea de Habermas promueve tres niveles de racionalidad legislativa penal que por su claridad resultan de gran utilidad práctica: a) ético-político, en cuanto a la consideración de los bienes jurídicos a proteger; b) pragmático, vinculado a la subsidiariedad y carácter de última ratio del Derecho Penal; y c) el de la coherencia, relativo a la validez constitucional y la adecuación político-criminal y dogmática de la propuesta legislativa ${ }^{19}$.

Ningún tipo de análisis o consideración en relación con la técnica legislativa empleada fue tenido en cuenta en el trámite legislativo de la Ley $N^{0}{ }^{19.889}$, fiel reflejo del populismo punitivista que la animara en relación con sus disposiciones penales. En cuanto a la normativa codificada, si las modificaciones parciales del articulado de los códigos ya constituyen un procedimiento desaconsejado, en tanto se altera la lógica interna de un cuerpo normativo que debe ser lógico, sistemático y armónico, con más razón ha de rechazarse que se lo haga a través de un procedimiento de urgencia. La Ley No 19.889 uruguaya no sólo modifica por este procedimiento anómalo el Código Penal, sino también el Código del Proceso Penal, el Código de la Niñez y la Adolescencia, el Código Civil y el Código General del Proceso. Adviértase entonces lo lejos que se está de respetar el principio de reserva de código, otra prueba del creciente distanciamiento entre los actores políticos y la Academia.

18 Oliver lalana, A. Daniel, "Los argumentos de eficacia en el discurso parlamentario", Doxa. Cuadernos de Filosofía del Derecho, № 31, Alicante, 2008, pp. 533-566.

19 Díez Ripoltés, José Luis, La racionalidad de las leyes penales. Práctica y teoría, Trotta, Madrid, 2003, pp. 90-91. 
Los principales desarrollos teóricos al respecto corresponden a FerRAJOLI, quien propone que se concrete en la máxima de que "...ninguna norma penal o procesal pueda dictarse si no es mediante una modificación o una integración de los códigos, aprobada, quizá, con procedimientos agravados"20; con ello, no solamente se persigue la existencia de procedimientos legislativos especiales y con mayorías cualificadas en atención a la gravedad de las consecuencias derivadas de la aplicación de tales preceptos, sino también contener la descontrolada inflación legislativa de las últimas décadas, la que ha generado un importante déficit en la certeza y cognoscibilidad de la legislación penal. En Uruguay, ha sido reclamado su respeto por penalistas como LACKNER Y MALET ${ }^{21}$, así como por quien suscribe ${ }^{22}$; en Colombia ha abogado en sentido similar, SOTOMAYOR ACOSTA 23 .

En materia penal, las modificaciones introducidas por la Ley No 19.889 continúan en la línea de la legislación uruguaya reciente en el sentido de desbaratar la dosimetría de las penas del Código Penal, generando nuevas incongruencias en desmedro de la armónica tutela de los bienes jurídicos en juego, conforme su relevancia. Cabe destacar llegado este punto, que el Código Penal uruguayo vigente, de 1934, es obra de José IRURETA GOYENA, eminente jurista pero a su vez, el más insigne representante de las clases acomodadas y el patriciado de su época, con lo que en aquél se refleja su pensamiento conservador, patriarcal y burgués. No en vano se ha sostenido que históricamente el bien jurídico mejor protegido en el Código Penal uruguayo ha sido la propiedad ${ }^{24}$. En nuestra obra sobre la reforma penal en Uruguay $^{25}$, advertíamos acerca de su benignidad legislativa frente a la delincuencia

20 Ferrajol, Luigl, “Garantías", Jueces para la Democracia Nº 38, Madrid, 2000, p. 43.

21 Lackner, Ricardo y Malet, Mariana, "Notas sobre el proyecto de reforma del Código Penal", Revista de Derecho Penal N 19, Fundación de Cultura Universitaria, Montevideo, 2011, p. 185.

22 Silva Fonné, La Reforma Penal, cit., pp. 37 y ss.

23 En dicha perspectiva, propone que "...valdría la pena pensar seriamente en la posibilidad de establecer ciertas exigencias en la motivación de las leyes penales (sin perjuicio de que dichas exigencias puedan extenderse a algunas otras materias o a todas en general), inclusive hasta implicar la obligatoriedad de ciertos requisitos básicos, que estarían plenamente justificados dado el carácter altamente aflictivo de la intervención penal. En particular, pareciera imprescindible que todo proyecto de ley acredite por lo menos su necesidad e idoneidad respecto de los objetivos perseguidos; así mismo debería prever los resultados esperados, de manera que facilite su evaluación posterior"; en SotomaYor AcostA, Juan Oberto, "Las recientes reformas penales en Colombia: un ejemplo de irracionalidad legislativa", Nuevo Foro Penal No 71, Universidad EAFIT, Medellín, 2007, p. 64.

24 Puig, Gustavo, "La dosimetría de las penas en el Código Penal uruguayo", Revista de Derecho Penal №18, Fundación de Cultura Universitaria, Montevideo, 2008, p. 670.

25 Silva Fonné, La Reforma Penal, cit., pp. 178 y ss. 
económica, en tanto se acentuaba el reduccionismo securitario. Así, mientras en la legislación penal contemporánea se han llevado a cabo importantes esfuerzos para enfrentar la delincuencia económica y empresarial, el legislador uruguayo concentra su afán punitivo en los delitos contra la propiedad visibles y mediáticos, quedando prácticamente fuera de su preocupación las maniobras o fraudes que vacían empresas, dejan en situación de desamparo a los trabajadores, atacan al medioambiente, lesionan los derechos de los consumidores, dañan gravemente al Fisco o hacen tambalear la Economía nacional.

Si bien el Uruguay en las últimas décadas ha aprobado normativa penal de avanzada en el contexto regional, como la regulación del mercado de la marihuana o la despenalización de la interrupción voluntaria del embarazo, correlativamente carece prácticamente de delitos penal-económicos y empresariales, al tiempo que sustraer una colmena rompiendo un candado, tiene la misma pena mínima que el homicidio intencional. Ello evidencia también el carácter esencialmente político de la legislación penal, cuando desde tribunas conservadoras se pretende reducir lo legislativo a una labor meramente técnica. En su justo término lo advertirían RivaCoBA y ZafFaron hace décadas: "Esto se produce, unas veces, desembozadamente, con rudeza manifiesta, $y$, otras, mediante procederes más sutiles, pero no menos eficaces, en que un afán de pureza técnica y de perfección formal distrae la atención de desigualdades, pretericiones e injusticias. Con frecuencia el excesivo formalismo en el derecho pierde de vista la realidad que éste ha de regular y los valores que deben informarle, y encubre o facilita situaciones que los burlan. Por lo demás, recrearse o refugiarse en la técnica al legislar, equivale a desconocer la naturaleza auxiliar de aquélla y olvidar que el legislador es por esencia un político y que quien le asesora cumple en lo fundamental una función política"26.

En cuanto a las disposiciones atinentes a la "seguridad pública" contenidas en el texto, no se apartan del modelo tradicional de populismo punitivista: incremento de las penas para los delitos de drogas, los delitos sexuales, normas penales que indirectamente criminalizan la disidencia y la pobreza, incremento en la represión de la infracción juvenil, restricciones a la excarcelación, nuevas potestades para la Policía; pero además inclusive, incidencia del Poder Ejecutivo en la toma de decisiones de los otros poderes del Estado, todo ello con prescindencia del texto constitucional y el Derecho Internacional de los DDHH, donde la eficacia buscada

26 Rivacoba y Rivacoba, Manuel y Zaffaroni, Eugenio Raúl, Siglo y medio de codificación penal en Iberoamérica, Edeval, Valparaíso, 1980, pp. 8-9. 
es exclusivamente electoral y mediática. En este marco, se hará mención a sus aspectos más cuestionables.

\section{Hacia un inconstitucional estado de policía}

El conjunto de la Ley No 19.889 se ve atravesado en sus diversos capítulos, por una concepción policializante de la vida en sociedad, a través de numerosas disposiciones inconstitucionales que limitan directa o indirectamente los derechos y libertades consagrados en la Carta fundamental. El personalismo democrático en función de los derechos humanos individuales y sociales que RAmón REAL reconociera en la Constitución uruguaya, se ve atacado en diversos artículos de esta ley por disposiciones que terminan consagrando un Estado de policía, el que la doctrina francesa caracterizara como, "... aquél en el cual la autoridad administrativa puede, de una manera discrecional y con una libertad de decisión más o menos completa, aplicar a los ciudadanos todas las medidas cuya iniciativa juzgue útil tomar por sí misma, en vista de hacer frente a las circunstancias y lograr en cada momento los fines que ella se propone: este régimen de policía está fundado sobre la idea de que el fin basta a justificar los medios"27.

Tanto en diversas modificaciones al Código del Proceso Penal como a la Ley de Procedimiento Policial, se amplían en forma injustificada las potestades policiales, con riesgo para las libertades republicanas. En dicho inconveniente catálogo se encuentra la ampliación del plazo de comunicación al Fiscal cuando la Policía actúa en su función de auxiliar de la justicia, la relajación en los requisitos para el uso legítimo de la fuerza, la detención administrativa de personas para tomarle declaraciones sin autorización fiscal, la ampliación de las facultades de registro personal y de sus pertenencias, así como la potestad de detener a una persona que si bien se ha identificado, no lleva en ese momento algún documento identificatorio consigo, para luego llevarlo a dependencias policiales con el objeto de tomarle fotos y huellas dactilares.

Se advertirá entonces su incompatibilidad con el sistema democrático y el Estado de Derecho, en varios casos por violación del primer inciso del artículo 10 de la Constitución uruguaya, que establece que "Las acciones privadas de las personas que de ningún modo atacan el orden público ni perjudican a un tercero, están exentas de la autoridad de los magistrados". La Carta Fundamental uruguaya, desde 1830,

27 Ramón Real, Alberto, “El 'Estado de Derecho' (Rechtsstaat)", en Ramón Real, Alberto, Estudios sobre Derecho Administrativo, Tomo III, Fundación de Cultura Universitaria, Montevideo, 1968, pp. 22-23. 
garantiza la libertad y autonomía personales, como piedra angular del sistema democrático. Si ni siquiera los magistrados pueden inmiscuirse en las acciones privadas de las personas que no atacan el orden público ni perjudican a terceros, mucho menos podrán hacerlo otros funcionarios públicos.

También se prevé la detención administrativa de testigos por hasta veinticuatro horas, cuando en la legislación anterior expresamente se prohibía; la flagrante inconstitucionalidad de esta nueva disposición emerge de los arts. 10 y 15 de la Constitución uruguaya ${ }^{28}$. Por otra parte y como ya se ha señalado precedentemente, el personal policial se arroga competencias del Ministerio Público al facultársele un interrogatorio autónomo en sus dependencias, por cuanto el encargado de llevar adelante la investigación criminal e interrogar a sospechosos y testigos es el Fiscal interviniente, siendo la Policía un auxiliar de éste. Véase que pareciera no importar que esa prueba luego carezca de validez en el proceso ${ }^{29}$; se trata de puro ejercicio de autoridad. Este debilitamiento de las garantías en la detención y procedimientos policiales fue señalado por la Institución Nacional de DDHH y Defensoría del Pueblo, afirmando que los cambios legislativos introducidos significan "un cambio profundo en la orientación de los principios doctrinarios que rigen a la Policía".

Con estas normas aprobadas, el flanco que se abre para la discrecionalidad y la corrupción policiales es amplísimo, lo mismo que para todo tipo de abusos y apremios físicos o psicológicos. Se trata de disposiciones antidemocráticas, lesivas de los arts. 7, 10 y 15 de la Constitución uruguaya ${ }^{30}$, así como del art. 9 del Pacto Internacional de Derechos Civiles y Políticos (PIDCP) y el art. 7 de la Convención Americana de Derechos Humanos (CADH). Implican la instalación de un régimen de inseguridad permanente, con quiebre del Estado de Derecho, que puede llegar a asemejarse al que la población experimentaba durante la dictadura militar en Uruguay.

28 Constitución uruguaya: Artículo 10. Las acciones privadas de las personas que de ningún modo atacan el orden público ni perjudican a un tercero, están exentas de la autoridad de los magistrados. Ningún habitante de la República será obligado a hacer lo que no manda la ley, ni privado de lo que ella no prohíbe. Artículo 15. Nadie puede ser preso sino infraganti delito o habiendo semiplena prueba de él, por orden escrita de Juez competente.

29 Lo que señalara la Asociación de Magistrados Fiscales del Uruguay en su informe ante el Parlamento.

30 Constitución uruguaya: Artículo $7^{\circ}$. Los habitantes de la República tienen derecho a ser protegidos en el goce de su vida, honor, libertad, seguridad, trabajo y propiedad. Nadie puede ser privado de estos derechos sino conforme a las leyes que se establecen por razones de interés general. 


\section{La desnaturalización de la legítima defensa}

La estructura de un instituto de aplicación estricta como la legítima defensa, se ve desarticulada por una lógica bélica que extiende irracionalmente la previsión especial para la tutela del hogar que esta justificante contiene, tanto a diversos establecimientos que no constituyen morada alguna, como a funcionarios policiales y militares.

La excepcionalidad de la presunción de legítima defensa, se fundamenta en la especial y privilegiada protección constitucional del hogar (art. 11) $)^{31}$, teniendo en cuenta la relevancia que tiene su amparo desde hace milenios en Occidente; es nada menos que la protección de la intimidad y seguridad de la familia, que recoge la Constitución uruguaya desde 1830.

Por ello es inadmisible constitucionalmente que se legisle una suerte de tutela privilegiada para algunas personas, como son las que quedan abarcadas por el numeral II) que se incorpora al art. $26 \mathrm{CPU}^{32}$. Ninguna de las nuevas previsiones de

31 Constitución uruguaya: Artículo 11. El hogar es un sagrado inviolable. De noche nadie podrá entrar en él sin consentimiento de su jefe, y de día, sólo de orden expresa de Juez competente, por escrito y en los casos determinados por la ley.

32 Art. 26 CPU (Legítima defensa). Se halla exento de responsabilidad el que obra en defensa de su persona o derechos, 0 de la persona o derechos de otro, siempre que concurran las circunstancias siguientes: A) Agresión ilegítima. B) Necesidad racional del medio empleado para repelerla o impedir el daño. El medio se considerará racional cuando resulte ser una respuesta suficiente y adecuada a fin de conjurar el peligro derivado de la agresión sufrida. Cuando la defensa deba ser ejercida respecto de cualquier derecho de contenido patrimonial, la racionalidad deberá ser apreciada con prescindencia de que no haya existido o ya hubiera cesado una agresión física a la persona que se defiende. C) Falta de provocación suficiente por parte del que se defiende. El tercer requisito no es necesario tratándose de la defensa de los parientes consanguíneos en toda la línea recta y en la colateral hasta el segundo grado inclusive, del cónyuge 0 concubino, 0 de los padres 0 hijos adoptivos, siempre que el defensor no haya tomado parte en la provocación. Se entenderá que concurren estas tres circunstancias respecto de: I) Aquel que defiende la entrada de una casa habitada o de sus dependencias, o emplea violencia contra el individuo extraño a ella que es sorprendido dentro de la casa o de las dependencias. Se considerarán dependencias de la casa, en las zonas urbanas: los balcones, terrazas, azoteas, parrilleros, barbacoas, jardines, garajes y cocheras o similares, siempre que tengan una razonable proximidad con la vivienda. Además, se considerarán dependencias de la casa en zonas suburbanas o rurales: los galpones, instalaciones o similares que formen parte del establecimiento, siempre que tengan una razonable proximidad con la vivienda. II) El funcionario del Ministerio del Interior o del Ministerio de Defensa Nacional que, en ocasión o con motivo del cumplimiento de sus funciones, repele una agresión física o armada contra él o un tercero, empleando las armas o cualquier otro medio de defensa en forma racional, proporcional y progresiva, en cuanto eso sea posible, y en las mismas circunstancias agote previamente los medios disuasivos que tenga a su alcance, sin perjuicio de la prueba en contrario. III) Aquel que repele el ingreso de personas extrañas, con violencia 0 amenazas en las cosas o personas o con la generación de una situación de peligro para la vida o demás derechos, en un establecimiento que desarrolle actividad 
legítima defensa presunta cuenta con apoyo constitucional, sino todo lo contrario.

Parece entonces que habría habitantes de la República que son "más personas" que otras, como si tuvieran derecho a una tutela superlativa de la ley respecto del resto de la ciudadanía. Resulta evidente que con ello hay una violación al principio de igualdad consagrado por el artículo $8^{\circ}$ de la Constitución uruguaya. Conforme el art. $7^{0}$ de ésta, todos sus habitantes tienen derecho a ser protegidos en el goce de su vida, honor, libertad, seguridad, trabajo y propiedad; y esta protección en el goce debe hacerse conforme con lo dispuesto por el art. $8^{\circ}$, en tanto todas las personas son iguales ante la ley; del mismo modo, se vulnera el art. 24 de la CADH.

Desde luego que puede legislarse en forma diferenciada recogiendo las situaciones particulares de determinados grupos de personas, buscando igualar sus posibilidades y satisfacer sus necesidades específicas (así, las medidas afirmativas para ciertos grupos vulnerables, o supuestos de discriminación positiva). También puede penalizarse más gravemente las conductas que atenten contra personas en situación de mayor exposición o riesgo, en tanto el sujeto activo se prevalezca de dicha vulnerabilidad.

Lo que no encuentra sustento alguno es que respecto de las personas que por su función ejercen la fuerza en nombre de la autoridad estatal -lo que debería conllevar se extremen los controles y límites para dicho ejercicio, en atención al cuidado que debe rodear la utilización legítima de la fuerza, para evitar su uso excesivo 0 abusivo-, precisamente de tales funcionarios públicos se presuma que en el ejercicio de su función represiva, han obrado en todo caso conforme a derecho. Se trata de una presunción innecesaria a la vez que sumamente riesgosa, sin perjuicio de que sea una presunción simple, esto es, que admite prueba en contrario.

Resulta contradictorio con sus funciones y su marco de actuación, el agregado de una presunción de legítima defensa respecto de estos agentes públicos, pues su cometido, instrucción y preparación tienen por objetivo enfrentar el riesgo y conjurarlo. Son las personas de la sociedad que han escogido cumplir una tarea -asumida voluntariamente- cuyo objetivo es el mantenimiento del orden y la seguridad públicos, asumiendo los riesgos que ello implica y teniendo perfectamente regulados los parámetros para el uso de la fuerza. Como afirmara con suma claridad JIMÉNEZ DE Asúa respecto del policía: "...la serenidad y la prudencia son en él obligaciones y no virtudes (...) Si no saben tener el valor para afrontar los peligros de su oficio, en vez

comercial, industrial o agraria en los términos establecidos por el artículo $3^{\circ}$ de la Ley $N^{\circ} 17.777$, de 21 de mayo de 2004. Redacción dada por el art. $1^{0}$ de la Ley No 19.889 de 09.07.2020. 
de guardianes del orden público se transforman en sus perturbadores principales" ${ }^{\prime 33}$.

Para peor y no obstante lo señalado precedentemente, se dispone que la defensa prevista para repeler el ataque en la presunción de legítima defensa para funcionarios del Ministerio del Interior o del Ministerio de Defensa Nacional, se ejercerá en "...forma racional, proporcional y progresiva, en cuanto eso sea posible...". Resulta increíble la inclusión de semejante dislate en el texto, por cuanto colisiona frontalmente con la naturaleza de la función policial por la cual se habilita al uso de la fuerza, así como con toda la normativa relativa al uso de la fuerza por los agentes estatales. Además, si el uso de la fuerza para defenderse, no es racional y proporcional, ya dejó de ser legítima defensa. Y si la presunción incluye estos parámetros -aún con el giro señalado-, habrá que valorarlos en el caso, con lo que la constatación del exceso hace caer la presunción simple; adviértase entonces que se trata de un agregado inútil, incluido para satisfacer intereses corporativos.

En relación con los funcionarios del Ministerio de Defensa Nacional, los cuerpos militares no tienen asignadas funciones relativas al orden y seguridad internos, las que corresponden al cuerpo policial. Las Fuerzas Armadas tienen asignada como competencia en el Uruguay, la defensa nacional (art. $7^{0}$, Ley No 19.775, Orgánica de las Fuerzas Armadas). Dos excepciones cuenta este cometido en el ordenamiento jurídico uruguayo vigente: a) La seguridad externa de establecimientos de detención (art. 77, Ley No 17.243; Ley No 18.717, prorrogada por las leyes $N^{0} 19.081,19.326$ y 19.507); b) Las tareas de vigilancia y apoyo en zonas fronterizas (Ley $\left.N^{0} 19.677\right)$.

La Ley Orgánica Policial uruguaya vigente, № 19.315, de 18.02.2015, dispone que "La Policía Nacional tiene como misión proteger el libre ejercicio de los derechos y libertades, y garantizar el orden y la seguridad interna...". Sin embargo, el numeral II) del nuevo art. $26 \mathrm{CPU}$, menciona en forma copulativa a los funcionarios "...del Ministerio del Interior o del Ministerio de Defensa Nacional", cuando éstos últimos no tienen asignada competencia alguna en relación al orden y seguridad internos, como acaba de verse. Por consiguiente, esta reforma no incide en absoluto en las bien diferenciadas tareas que tienen ambos cuerpos armados, es decir, las Fuerzas Armadas seguirán careciendo de injerencia alguna en el mantenimiento del orden y seguridad internos.

En cuanto a la presunción de legítima defensa de diversos establecimientos prevista en el numeral III) del artículo a examen, carece de toda legitimidad, en tanto al fin y en cuanto al uso que se pretendería hacer de ella conforme el discurso

33 Jiménez de asúa, Luis, Tratado de Derecho Penal, Tomo IV, 2ª edición, Ed. Losada, Buenos Aires, 1961, pp. 564-565. 
securitario a que responde. No admite la más mínima equiparación con la defensa del hogar. Al mismo tiempo, puede dar a entender equivocadamente, que se trata de una licencia para matar, haciendo primar el derecho de propiedad por sobre la vida 0 integridad física de las personas. Dicha visión se sustenta en la burda concepción mediática y populista neoliberal que recrea un mundo de personas buenas y honradas, frente a una masa ingente de criminales que se configura a través de estereotipos, los cuales constituyen "los otros", a los cuales hay que combatir porque ponen en peligro a "nosotros" los honestos.

Un entendimiento asistemático sobre esta norma, genera el riesgo de producir un incremento masivo en la tenencia de armas de fuego, de los enfrentamientos armados, de las muertes en éstos (pues si los titulares de cualquier establecimiento comercial, industrial o agrario se sintiesen ahora con licencia para matar, los delincuentes ya comenzarían atacándolos antes que los abatieran a ellos), de los intentos de aplicar justicia por mano propia, del recurso a la violencia para resolver conflictos como norma y no como excepción, del tráfico de armas, del sicariato, etc., degradando a la Policía Nacional en sus cometidos por cuanto los particulares los habrían asumido para sí. Este estado de guerra de "todos contra todos" (cual hobbesiano homo homini lupus) es precisamente la antítesis de la convivencia pacífica y el respeto a las libertades ciudadanas que garantiza la Constitución e impone el Derecho Internacional de los Derechos Humanos, e implica el repliegue del Estado de uno de sus cometidos fundamentales.

En definitiva, ninguna de estas dos nuevas hipótesis de legítima defensa presunta son aceptables y reclaman de la dogmática jurídico penal una interpretación estricta y conforme el conjunto del ordenamiento jurídico vigente, descartando toda interpretación de cuño bélico. Lo contrario sería incumplir los estándares internacionales a los que se ha comprometido el Uruguay en cuanto al uso legítimo de la fuerza y la conducta de los funcionarios encargados de hacer cumplir la ley, desnaturalizar el instituto de la legítima defensa, ignorar la distribución orgánica de competencias estatales propia de un Estado de Derecho, ambientando en definitiva, un estado de situación que propiciaría el llamado "gatillo fácil".

\section{El retorno de la fracasada "guerra a las drogas"}

Con la aprobación de la Ley N N 19.889, en los delitos de estupefacientes se produce un incremento desmesurado de las penas, abarcando inclusive conductas delictivas leves o muy poco graves, a las que se las castiga con la misma pena mínima -o superior aún- que para el delito de homicidio intencional. Semejante aberración 
jurídica puede llevar a un incremento exponencial del encarcelamiento y, por ende, de la superpoblación penitenciaria (téngase presente que los delitos de drogas son la segunda causa de prisionización en Uruguay, después de los delitos contra la propiedad), degradando aún más las condiciones de la privación de libertad, a la vez que generando más violencia y favoreciendo la corrupción policial y penitenciaria.

Esta nueva modificación legislativa en materia de delitos de drogas, salvo por el mantenimiento del régimen especial emergente de la regulación del mercado de la marihuana, retrotrae a los tiempos de la dictadura militar, pero aún peor, estableciendo penas más severas que las previstas por el legislativo de aquel régimen ${ }^{34}$, así como concatenando estos excesos punitivos con la limitación de institutos liberatorios y mecanismos de reinserción social, vulnerando el art. 26 de la Constitución uruguaya ${ }^{35}$; la demonización de las conductas vinculadas a sustancias psicoactivas es tal, que se parifica a efectos de la aplicación de estos institutos cualquier conducta relativa a drogas, tanto el narcotráfico en el marco del crimen organizado, como el microtráfico 0 el ingreso de cantidades mínimas a establecimientos carcelarios por parte de la pareja o familiares del recluso.

Se trata del retorno de la "guerra a las drogas", modelo bélico que ha demostrado ser ineficaz, inútil, generador de violencia, corrupción y un baño de sangre en todo el continente. El irreal paradigma de "un mundo sin drogas" emergente de las convenciones de Naciones Unidas en la materia, desde la década pasada comenzó a ser abandonado paulatinamente en Occidente, en un proceso internacional pausado pero irreversible, basado en criterios de salud pública y reducción de riesgos y daños ${ }^{36}$, del cual ahora Uruguay parece apartarse, retomando una tónica punitivista que lo haría retroceder setenta años en el tratamiento del tema.

34 Uruguay padeció una dictadura cívico-militar entre 1973 y 1984; este período a su vez, se había visto precedido de un decaecimiento del Estado de Derecho con medidas de Estado de excepción, entre 1968 y 1972.

35 Constitución uruguaya: Artículo 26. A nadie se le aplicará la pena de muerte. En ningún caso se permitirá que las cárceles sirvan para mortificar, y sí sólo para asegurar a los procesados y penados, persiguiendo su reeducación, la aptitud para el trabajo y la profilaxis del delito.

36 Silva Fonné, Diego, Drogas y Derecho Penal en el Uruguay. Tolerancia, prohibición, regulación, Fundación de Cultura Universitaria, Montevideo, 2016, pp. 37 y ss.; Silva Forné, Diego, Regulación de la Marihuana. Drogas y Estado de Derecho. El modelo regulatorio de Uruguay. La situación en España, Instituto Andaluz Interuniversitario de Criminología Sección Granada - Ed. Dykinson, Madrid, 2018, pp. 55 y ss. 


\section{Criminalización de la disidencia, la protesta y la pobreza}

La Ley No 19.889 crea nuevas figuras delictivas en forma innecesaria, por cuanto en muchos casos se trata de conductas ya previstas como delictivas por la legislación vigente. A su vez, se introducen nuevas figuras delictivas que reprimen penalmente a individuos porque la Policía no cumplió eficazmente con su labor, esto es, el sinsentido de crear un delito para penalizar a alguien, pero por la ineficiencia de la labor policial a su respecto. Tales casos se advierten en el absurdo delito de "resistencia al arresto" incorporado como art. 173 bis al CPU ${ }^{37} 0$ en la modificación del delito de autoevasión, reprimiendo la mera fuga sin violencia.

De forma indirecta, la Ley No 19.889 criminaliza comportamientos vinculados a la expresión de la disidencia, la protesta y las manifestaciones públicas populares. Ello se hace a través de la introducción de disposiciones que, con el argumento de la mejor tutela de los funcionarios policiales, castiga con penas privativas de libertad conductas vagas e indeterminadas sujetas en gran medida a la subjetividad del intérprete, donde pareciera que para impedir todo tipo de obstaculización o agravio de cualquier naturaleza a los funcionarios policiales, no solamente éstos pasarían a contar con un estatus diferenciado respecto del resto de la ciudadanía frente a conductas nimias, sino que posibilitaría la represión penal de cualquier movilización social en que la población tenga el más mínimo contacto con las fuerzas policiales; el ejemplo más claro es la innecesaria figura delictiva de "agravio a la autoridad policial", incorporado al CPU como art. 173 ter $^{38}$. A su vez, las modificaciones introducidas en la falta de ocupación indebida de espacios públicos prevista por

37 Código Penal uruguayo: Art. 173 bis. (Resistencia al arresto). El que, al recibir orden de detención de parte de una autoridad pública ejerciera resistencia física al arresto, será castigado con una pena de seis meses de prisión a tres años de penitenciaría. Con la misma pena será castigado el que intentara impedir la detención de otra persona, oponiendo resistencia física, obstruyendo la acción de la autoridad, o facilitara su fuga. Si en la resistencia al arresto se agrediera 0 atentara contra la autoridad pública, la pena será de seis meses de prisión a cuatro años de penitenciaría.

38 Código Penal uruguayo: Art. 173 ter (Agravio a la autoridad policial). El que obstaculice, agravie, atente, arroje objetos, amenace 0 insulte a la autoridad policial en ejercicio de sus funciones 0 con motivo de estas, será castigado con una pena de tres a dieciocho meses de prisión. No serán castigados el ejercicio de la libertad de prensa ni la mera protesta ante la acción policial. Son circunstancias agravantes para este delito y ameritan la imposición de un guarismo punitivo superior a la mitad de la pena: 1. Que la conducta descripta se ejercite por tres o más personas. 2. Que la conducta descripta se ejecute contra un número plural de funcionarios. 3. La elevación jerárquica del funcionario ofendido. 4. Que la conducta descripta se realice en las inmediaciones de la sede donde el funcionario presta servicio habitualmente o del domicilio del mismo. Es circunstancia atenuante, la retractación del ofensor, aceptada por el funcionario en cuestión, manifestada y asentada en audiencia. 
el art. 368 del Código Penal ${ }^{39}$, terminan por criminalizar la indigencia, abriendo al mismo tiempo una nueva brecha para la discrecionalidad y la corrupción policiales.

Se trata de otro caso más donde se privilegia la tutela jurídico-penal de las fuerzas policiales en desmedro de los derechos de la ciudadanía, ya sea por una nueva violación del principio de igualdad así como por restricciones oblicuas a la libertad de expresión, que inclusive pueden llevar a la autocensura.

\section{Violación del principio de separación de poderes}

La separación de poderes es un pilar fundamental, inmanente al sistema republicano democrático de gobierno. La creación de un Consejo de Política Criminal y Penitenciaria en la órbita del Ministerio del Interior y presidido por su representante, que debe emitir recomendaciones en forma previa no vinculante a todo proyecto de ley que incida "...en la política criminal, y en el funcionamiento del sistema penitenciario o sistema penal juvenil", resulta inadmisible, por cuanto el Poder Legislativo no puede estar sometido a condicionamiento alguno en lo que hace relación a la función legislativa conforme los parámetros constitucionales. Por su parte, la formulación de "...recomendaciones sobre la estructura de la justicia penal, con el objeto de dotarla de la mayor eficiencia en la lucha contra el delito" atenta contra la independencia del Poder Judicial. A su vez, el cometido de emitir opinión con destino a la Fiscalía General de la Nación "...sobre los lineamientos generales de la política criminal, que deberán ser tenidos en cuenta al momento de aplicar el principio de oportunidad previsto en el artículo 100 del Código del Proceso Penal", vulnera derechamente la independencia técnica de los Fiscales, recibiendo indicaciones sobre su actuar por parte de un organismo dependiente del Poder Ejecutivo. El resquebrajamiento del Estado de Derecho y de la separación de poderes culmina con que se comete al Poder Ejecutivo que procure que lo actuado por el Consejo sea reconocido y tenido en cuenta por todos los órganos del Estado que tengan injerencia en la materia (arts. 88 a 94, Ley $N^{0} 19.889$ ).

39 Código Penal uruguayo: Art. 368 (Ocupación indebida de espacios públicos). El que (...) ocupare espacios públicos acampando o pernoctando en ellos, será intimado por parte de la autoridad departamental, municipal o policial correspondiente a retirarse en forma inmediata y a que desista de su actitud. De permanecer o persistir, será castigado con una pena de siete a treinta días de prestación de trabajo comunitario. Siempre que se constaten las conductas referidas, la persona será trasladada a una dependencia del Ministerio de Desarrollo Social a los efectos de que se recabe su identidad, se le ofrezca una alternativa adecuada a su situación y se dé cuenta al Juez competente. 


\section{Hacia el colapso del sistema penitenciario}

La Ley N 19.889 desnaturaliza el instituto de la prisión preventiva y debilita el régimen de salidas transitorias de los reclusos. En efecto, se modifican normas alterando una vez más el carácter de la prisión preventiva como medida cautelar, excepcional en el marco de un proceso penal de carácter acusatorio. Al establecer su preceptividad para diversos delitos ${ }^{40}$, se ratifica la utilización de la prisión preventiva como un "adelanto de pena", lo que colisiona frontalmente con la lógica del sistema acusatorio, donde la regla es la tramitación del proceso en libertad y la excepción la prisión preventiva, que sólo se justifica en situaciones de riesgo para la administración de justicia, partes o testigos, conforme los principios procesales que rigen la aplicación de medidas cautelares.

Al mismo tiempo, con la incorporación de nuevas restricciones para su aplicación, mengua el régimen de salidas transitorias, que tiene por objeto incorporar paulatinamente al recluso en la sociedad, con miras a su reinserción. Como han afirmado claramente LACKNER Y MALET, “... las salidas transitorias son un instituto que se enmarca dentro de la concepción progresiva del régimen de reclusión, conforme lo dispuesto por el Capítulo V del D.L. 14.470 y por las Reglas Mínimas para el Tratamiento de los Reclusos, adoptadas por Naciones Unidas, artículo 60. En otros términos, se procura preparar gradualmente al recluso para su retorno a la sociedad, conforme a la filosofía que inspira el artículo 26 de la Carta. No se trata, pues, de un

40 Código del Proceso Penal uruguayo: Art. 224. (Requisitos para disponer la prisión preventiva). 224.1 Iniciado el proceso y a petición del Ministerio Público, el tribunal podrá decretar la prisión preventiva del imputado si hubiera semiplena prueba de la existencia del hecho y de la participación del imputado y elementos de convicción suficientes para presumir que intentará fugarse, ocultarse 0 entorpecer de cualquier manera la investigación o que la medida es necesaria para la seguridad de la víctima 0 de la sociedad (artículo 15 de la Constitución de la República). A estos efectos, el tribunal podrá acceder a la carpeta fiscal. 224.2 El riesgo de fuga, el ocultamiento, el entorpecimiento de la investigación, así como el riesgo para la seguridad de la víctima y de la sociedad, se presumirá cuando el Ministerio Público imputare alguna de las siguientes tipificaciones delictuales: A) Violación (artículo 272 del Código Penal). B) Abuso sexual, cuando la violencia se presume de acuerdo a las situaciones previstas por los numerales $1^{\circ}$ a $4^{\circ}$ del artículo 272 BIS del Código Penal. C) Abuso sexual especialmente agravado (artículo 272 TER del Código Penal). D) Atentado violento al pudor, cuando el sujeto pasivo del delito fuese un menor de doce años (artículo 273 del Código Penal). E) Rapiña (artículo 344 del Código Penal). F) Rapiña con privación de libertad. Copamiento (artículo 344 BIS del Código Penal). G) Extorsión (artículo 345 del Código Penal). H) Secuestro (artículo 346 del Código Penal). I) Homicidio agravado (artículos 311 y 312 del Código Penal). J) Los crímenes y delitos contenidos en la Ley $N^{0} 18.026$, de 25 de setiembre de 2006. K) Los delitos previstos en el DecretoLey $N^{0} 14.294$, de 31 de octubre de 1974, y sus modificativas, que tuvieren penas mínimas de penitenciaría. L) Los delitos previstos en la Ley No 19.574, de 20 de diciembre de 2017, que tuvieren pena mínima de penitenciaría. 224.3 En los casos previstos en el inciso 224.2, el Ministerio Público deberá solicitar la prisión preventiva. 
instituto gracioso de clemencia soberana, ni tampoco de una potestad administrativa arbitrariamente ejercida. Es un derecho de la persona privada de libertad, condicionado al cumplimiento de determinados requisitos previstos taxativamente por la ley" ${ }^{\prime \prime 1}$.

Se trata ni más ni menos del incuestionable derecho a prepararse gradualmente para la vida en libertad al egreso, en tanto la privación de libertad persigue "...la reeducación, la aptitud para el trabajo y la profilaxis del delito" (art. 26, Constitución uruguaya). Tal cometido resulta imposible sin un progresivo reintegro a la sociedad, tras las modalidades de cumplimiento de pena que la ley establece.

Por otra parte y como se adelantara, la prisión preventiva se aplicará ahora preceptivamente a conductas que no necesariamente han sido graves, por ejemplo, los delitos de drogas sin distinción alguna (Decreto-ley No 14.294), incluyendo situaciones de microtráfico, ingreso de drogas por madres o esposas a establecimientos carcelarios para consumo de su familiar interno, o tráfico de subsistencia. Resulta entonces muy significativo que en este catálogo de delitos, no se haya incluido por ejemplo la corrupción del funcionario público especialmente agravada por la condición de funcionario policial, teniendo en cuenta que este mal endémico en el continente no ha sido erradicado ni mucho menos de los cuerpos policiales locales.

En cuanto a las nuevas restricciones y la prohibición del régimen de redención de la pena por trabajo 0 estudio para determinados delitos ${ }^{42}$, colisiona con el propósito del régimen penitenciario vigente en Uruguay (Decreto-ley $\mathrm{N}^{0}{ }^{14.470)}$ así como con las Reglas para el Tratamiento de los Reclusos de Naciones Unidas (Reglas Mandela); inclusive con el texto constitucional uruguayo, en tanto como se vio, la privación de libertad persigue la reeducación y la aptitud para el trabajo.

41 Lackner y Malet, "Apuntes...", cit., p. 176.

42 Ley No 17.897, en la redacción dada por el art. 86 de la Ley No 19.889: Art. 13. (Redención de pena por trabajo o estudio). El Juez concederá la redención de pena por trabajo a los condenados a pena privativa de libertad. (...) Para el caso de los siguientes delitos: artículos 30, 33, 34 y 35 del Decreto-Ley No 14.294, de 31 de octubre de 1974, y sus modificativas (estupefacientes), rapiña (artículo 344 del Código Penal), privación de libertad (artículo 281 del Código Penal), lesiones graves y gravísimas (artículos 317 y 318 del Código Penal), extorsión (artículo 345 del Código Penal) y homicidio intencional (artículo 310 del Código Penal), la exigencia de trabajo o estudio para redimir pena se les conmutará a razón de un día de reclusión por tres días de trabajo y de un día de reclusión por tres días de estudio. Quedan excluidos del presente régimen de redención de pena por trabajo o estudio, los condenados por los delitos previstos en los artículos 31, 32 y 36 del Decreto-Ley NN 14.294, de 31 de octubre de 1974, y sus modificativas (estupefacientes), el delito de violación (artículo 272 del Código Penal), de abuso sexual y de abuso sexual especialmente agravado (artículos 272 BIS y 272 TER del Código Penal), de homicidio especialmente agravado y muy especialmente agravado (artículos 311 y 312 del Código Penal), de rapiña con privación de libertad. Copamiento (artículo 344 BIS del Código Penal) y de secuestro (artículo 346 del Código Penal). 
Por otra parte y como destaca el informe CIEPUR-GEPCU ya citado, la limitación de las alternativas a la privación de libertad, con la derogación de la suspensión condicional del proceso y la instalación de un régimen de libertad a prueba de aplicación más restrictiva que la libertad vigilada que también se deroga con esta ley, hará que en causas de menor entidad la única salida posible al conflicto penal sea la privación de libertad.

En lo que va del siglo XXI se ha triplicado la población penitenciaria en Uruguay, alcanzando cerca de doce mil personas privadas de libertad, cifra que lo sitúa en segundo lugar después de Brasil en América del Sur, con una tasa de prisionización de 328 presos cada cien mil habitantes. Dicha cifra sorprende en tanto no coincide con los niveles de violencia de la sociedad uruguaya. Por otra parte, sin perjuicio de algunas mejoras importantes en los últimos años, aún cerca del $75 \%$ de los reclusos se encuentra en centros que no ofrecen posibilidades de rehabilitación para su posterior reinserción social, así como un tercio de ellos se halla en condiciones de reclusión que conforme los estándares internacionales, constituyen tratos crueles, inhumanos y degradantes.

Paralelamente, entre las modificaciones al Código de la Niñez y la Adolescencia contenidas en la Ley $N^{0}$ 19.889, se duplica el período de tiempo de privación de libertad previsto en la ley como respuesta última a la infracción adolescente, en sentido contrario a las pautas establecidas por la Convención Internacional de Derechos del Niño, lo que fuera expresamente cuestionado por UNICEF. Y precisamente ello se produce cuando se observa una sensible disminución en el número de infracciones adolescentes en los últimos años, con lo cual la medida carece de todo fundamento, aun del securitario. Junto con el endurecimiento en la represión de los delitos de drogas, se advierte que se persigue únicamente reafirmar los estereotipos en torno a los jóvenes infractores y las conductas vinculadas a las drogas ilegales, con propósitos puramente simbólicos y electorales.

En definitiva, en estos artículos se ignora la finalidad constitucional de la privación de libertad así como la actual situación penitenciaria en el país. Indirectamente, con este erróneo incremento de la prisionización se está tendiendo a una explosión de la superpoblación carcelaria, de consecuencias impredecibles.

Si bien no puede afirmarse que se trate de una situación buscada, este resultado es perfectamente funcional al modelo de sociedad a que aspira el populismo punitivista: un sistema penitenciario colapsado carece de capacidad alguna para evitar la desocialización de su población, mucho menos para intentar su reinserción social; al egreso, esta masa de excluidos tiene la mayor chance de permanecer atada 
al sistema penal a raíz de las múltiples nuevas exclusiones derivadas de su estatus, con lo que sus posibilidades de marginación y reincidencia son enormes. Véase, para poner un caso, que entre la población en situación de calle ${ }^{43}$ en Uruguay en 2019, el $82 \%$ contaba con trayectoria vital en instituciones totales y el $69 \%$ declaró haber pasado por el sistema penitenciario.

La "clientela" perpetua del sistema penal, que ya no tiene más que perder, retroalimenta el discurso punitivista y de la otredad, confirmando el estereotipo criminal de que se vale aquél y por ende, proveyendo inacabadamente de nuevos destinatarios para la vidriera de las miserias humanas, donde el sistema penal y mediático expone a aquéllos a quienes pretende repeler la sociedad de la seguridad (e inseguridad de la mayoría).

\section{Balance}

La Ley N 19.889 contiene normas de dudosa constitucionalidad y otras de inconstitucionalidad flagrante. Por otra parte, su aprobación contó con dos graves déficits democráticos singulares: a) la utilización de un procedimiento de urgente consideración para su tratamiento legislativo, instituto previsto constitucionalmente para atender situaciones puntuales que requirieran soluciones inmediatas, que en este caso se desnaturalizó al tramitar un proyecto de ley de más de quinientos artículos contentivo de casi todos los temas del quehacer nacional, además de modificaciones a varios Códigos; b) la tramitación de un proyecto de ley de tanta relevancia, que afecta numerosos temas de incidencia directa en la población, se llevó a cabo en medio de la mayor pandemia que ha experimentado la Humanidad en los últimos cien años, donde la ciudadanía se encontraba sujeta a medidas sanitarias de control que impedían ejercitar el derecho de reunión, la libre comunicación del pensamiento, así como las manifestaciones públicas de disidencia, discrepancia 0 protesta ante las propuestas legislativas.

Si bien no se produjo la sanción ficta de la ley por el vencimiento de los plazos previstos constitucionalmente y el proyecto experimentó varias modificaciones durante su discusión, la labor parlamentaria se vio severamente alterada, imposibilitando el tratamiento serio y reflexivo que imponía el enorme conjunto de temas a consideración y su singular trascendencia. El procedimiento empleado constituyó un fraude a la Constitución, a través del abuso de un instituto constitucional

43 Situación de calle refiere a personas que habitan a la intemperie en espacios públicos y llevan consigo sus pertenencias, sin un lugar que pueda caracterizarse como vivienda. También se considera a las personas que habitan en refugios o centros nocturnos, que no tienen un alojamiento estable. 
por parte del propio gobierno. Lamentablemente en nuestro continente, no es el primer caso en que se emplean este tipo de procedimientos con diversos fines.

De esta forma, no sólo fue limitada ilegítimamente la labor de los representantes del pueblo, constreñidos a considerar en plazos exiguos una desmesura de temas del que difícilmente pudiera predicarse la urgencia requerida por la Carta en alguno de ellos, sino que tampoco la ciudadanía contó con el pleno ejercicio de sus libertades para manifestarse libremente expresando tanto su apoyo como su descontento, ya que inadmisiblemente, este trámite anómalo se llevó a cabo en un momento álgido de la pandemia que hoy experimenta la comunidad internacional. Esta fractura del Estado de Derecho no puede dejar de señalarse enfáticamente, no sólo para demandar una profunda reflexión de las fuerzas democráticas, sino además, para que no sea luego utilizada como legitimador precedente.

Cualquiera sea el problema que se trate de enfrentar, el Estado social y democrático de Derecho garantizado por la Constitución no permite que el fin justifique los medios. Los derechos fundamentales y sus garantías son innegociables. No es siquiera hacer cuestión de la prohibición de retorno en materia de avances en derechos ciudadanos que hoy consagra y defiende el Derecho Internacional de los Derechos Humanos. Se trata ni más ni menos que de garantizar el legado de siglos de esforzada construcción libertaria, igualitaria y democrática, que constituye núcleo central de las Cartas Fundamentales de las repúblicas latinoamericanas.

El debilitamiento del Estado de Derecho en la región a través de la desnaturalización de institutos y potestades consagradas constitucionalmente, no se ha utilizado en este caso para la remoción de autoridades legítimamente electas, ni para la persecución política mediante la estrategia de lawfare, ni para habilitar un estado de excepción, sino para la consagración normativa de medidas de populismo punitivo, difícilmente aceptadas a través de procedimientos legislativos regulares, que permiten una discusión parlamentaria reflexiva y con la participación activa de la sociedad civil. Para peor, el caso uruguayo analizado se produjo en el marco de las restricciones sanitarias por la pandemia de covid-19.

Cada vez resulta más evidente que se hace necesario blindar el proceso legislativo de las normas que limitan derechos fundamentales. La ley penal, por su desmesurada utilización en la actualidad, es el ejemplo donde esta necesidad resulta quizás más acuciante. Su sanción requeriría, de lege ferenda, procesos reglados constitucionalmente y la exigencia de mayorías calificadas, que limitaran la posibilidad de su utilización populista en mérito a mayorías parlamentarias coyunturales. 


\section{Bibliografía}

Asociación de Magistrados Fiscales del Uruguay, Informe de 15.06.2020. Recuperado de https://parlamento.gub.uy/documentosyleyes/ficha-asunto/146733; consulta: 16.07.2020.

Bauman, Zygmunt (2007), Miedo líquido. La sociedad contemporánea y sus temores (Liquid Fear, Polity Press, Cambridge, 2006; traducción de Albino Santos Mosquera), Paidós, Barcelona.

Bustos Ramírez, Juan (2006), "Seguridad ciudadana y seguridad jurídica", Nuevo Foro Penal Nº 70, Universidad EAFIT, Medellín.

Cajarville Peluffo, Juan Pablo (2020), "La Ley de Urgencia", Búsqueda, Montevideo, 27.02.2020.

Castel, Robert (2004), La inseguridad social ¿Qué es estar protegido? (L'insécurité sociale. Qu'est-ce qu'être protégé?, Éditions du Seuil et La République des Idées, Paris, 2003; traducción de Viviana Ackerman), Ediciones Manantial, Buenos Aires.

Centro de Investigaciones y Estudios Penales del Uruguay "Dra. Adela Reta" (CIEPUR) y Grupo de Estudios en Política Criminal (GEPCU), Informe al Senado sobre el proyecto de ley de urgente consideración, comparecencia del 22.05.2020. Recuperado de https://parlamento.gub.uy/documentosyleyes/ficha-asunto/145885/ficha completa; consulta: 20.07.2020.

Comisionado Parlamentario Penitenciario, Infome Preliminar 2019, Poder Legislativo, Uruguay. Recuperado de https://parlamento.gub.uy/cpp/documentos/informes; consulta: 20.07.2020.

Díez Ripollés, José Luis (2003), La racionalidad de las leyes penales. Práctica y teoría, Trotta, Madrid.

Ferrajol,, Luigi (2000), "Garantías", Jueces para la Democracia No 38, Madrid.

Garland, David (2005), La cultura del control. Crimen y orden social en la sociedad contemporánea (The Culture of Control-Crime and Social Order in Contemporary Society, Oxford University Press, 2001; traducción de Máximo Sozzo), Gedisa, Barcelona.

Institución Nacional de DDHH y Defensoría del Pueblo, Tercer informe sobre el proyecto de ley con declaratoria de urgente consideración. Recuperado de: https:// www.gub.uy/institucion-nacional-derechos-humanos-uruguay/comunicacion/ noticias/nuevo-informe-inddhh-sobre-ley-urgente-consideracion; descarga: 18.07.2020 
Institute for Economics and Peace, Global Peace Index (2019 y 2020). Recuperado de http://economicsandpeace.org/reports; consulta: 18.07.2020.

Jiménez de Asúa, Luis (1961), Tratado de Derecho Penal, Tomo IV, 2a edición, Ed. Losada, Buenos Aires.

Kessler, Gabriel (2011), El sentimiento de inseguridad. Sociología del temor al delito, Siglo XXI, Buenos Aires.

Kury, Helmut/ Ferdinand, Theodore (1999), “Miedo al delito, tamaño de la población, salidas a la calle y actitudes hacia la policía. Resultados alemanes", Revista de Derecho Penal y Criminología, $2^{a}$ época, No 3, U.N.E.D., Madrid.

Lackner, Ricardo y Malet, Mariana (2011), "Notas sobre el proyecto de reforma del Código Penal", Revista de Derecho Penal № 19, Fundación de Cultura Universitaria, Montevideo.

Mosteriro, Mariana/ Samudo, Tamara et al. (2016), "Adolescentes, jóvenes y violencia policial en Montevideo. Una aproximación descriptiva", Cuadernos de Ciencias Sociales y Políticas Sociales N 6, SERPAJ - IELSUR - Facultad de Ciencias Sociales - Facultad de Ciencias Económicas y Administración - Ministerio de Desarrollo Social, Montevideo.

Oliver lalana, A. Daniel (2008), "Los argumentos de eficacia en el discurso parlamentario", Doxa, Cuadernos de Filosofía del Derecho, № 31, Alicante.

PNUD. Informe sobre Desarrollo Humano 2019. Recuperado de http://hdr.undp. org/sites/default/files /hdr_ 2019 _ overview _ _ _ spanish.pdf; descarga: 24.06.2020.

Puig, Gustavo (2008), "La dosimetría de las penas en el Código Penal uruguayo", Revista de Derecho Penal No 18, Fundación de Cultura Universitaria, Montevideo.

Ramón Real, Alberto (1968), "El 'Estado de Derecho' (Rechtsstaat)", en Ramón Real, Alberto, Estudios sobre Derecho Administrativo, Tomo III, Fundación de Cultura Universitaria, Montevideo.

Ribeiro Giambardino, André (2015), "A construção social do medo do crime e a violencia urbana no Brasil", Revista Brasileira de Ciências Criminais, vol. 115, ano 23, IBCCrim/Thomson Reuters/Revista dos Tribunais, São Paulo.

Rivacoba y Rivacoba, Manuel y Zaffaroni, Eugenio Raúl (1980), Siglo y medio de codificación penal en Iberoamérica, Edeval, Valparaíso.

Silva Forné, Diego (2012), La Reforma Penal. El derecho vigente. Modificaciones proyectadas. Alternativas, Fundación de Cultura Universitaria, Montevideo. 
Silva Forné, Diego (2016), Drogas y Derecho Penal en el Uruguay. Tolerancia, prohibición, regulación, Fundación de Cultura Universitaria, Montevideo.

Silva Fonné, Diego (2018), Regulación de la Marihuana. Drogas y Estado de Derecho. El modelo regulatorio de Uruguay. La situación en España, Instituto Andaluz Interuniversitario de Criminología Sección Granada - Ed. Dykinson, Madrid.

Simon, Jonathan (2011), Gobernar a través del delito (Governing Through Crime: How the War on Crime Transformed American Democracy and Created a Culture of Fear, Oxford University Press, New York, 2007; traducción de Victoria de los Ángeles Boschiroli), Gedisa, Barcelona - México D. F.

Sotomayor Acosta, Juan Oberto (2007), "Las recientes reformas penales en Colombia: un ejemplo de irracionalidad legislativa", Nuevo Foro Penal No 71, Universidad EAFIT, Medellín.

Terradillos Basoco, Juan (2005). Las reformas penales españolas de 2003: valoración político-criminal, Nuevo Foro Penal Nº 67, Universidad EAFIT, Medellín.

Terradillos Basoco, Juan (2016), “Caracteres y Principios Generales del Derecho Penal Económico y de la Empresa", en Silva Fonné, Diego / Uval, Natalia (Coords.), Reforma del Código Penal. Aportes de las organizaciones sociales y de juristas internacionales, Cámara de Representantes - Oficina de Planeamiento y Presupuesto - Unión Europea, Montevideo.

UNICEF. Informe de 19.06.2020. Recuperado de https://parlamento.gub.uy/ documentosyleyes/ ficha-asunto/ 146673; consulta: 18.07.2020.

Wacouant, Loïc (2010), Castigar a los pobres. El gobierno neoliberal de la inseguridad social (Punishing the Poor. The Neoliberal Government of Poverty, Duke University Press, Durham and London, 2009; traducción de Margarita Polo, Diego P. Roldán y Cecilia Pascual), Gedisa, Barcelona. 